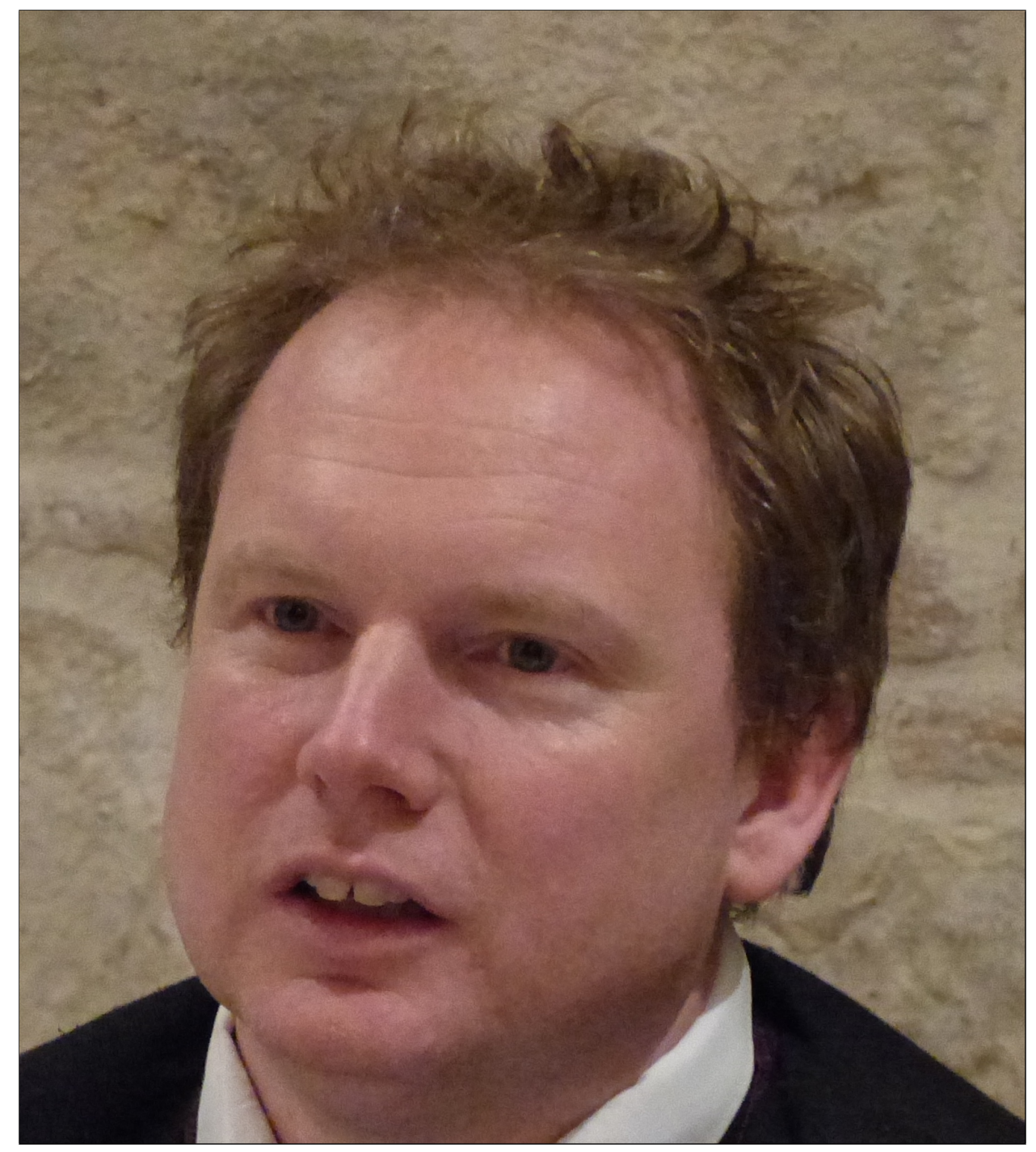

Csanád Imreh (1975-2017) 



\section{In memoriam Csanád Imreh (1975-2017)}

The present volume is a collection of papers dedicated to the memory of Professor Csanád Imreh, who passed away unexpectedly in 2017. These papers were written by his friends, colleagues and former students.

Csanád Imreh was born in Szeged on 20th May in 1975. His interest in mathematics emerged quite early. He started to work for the "Középiskolai Matematikai Lapok" "Mathematical letters for secondary schools", a special journal for mathematically talented secondary school students) at the upper elementary school. He continued to participate in different competitions when he was a secondary school student. He attended a special class for mathematically talented youngsters in Szeged.

At the university he studied mathematics, but he was already interested in algorithmic problems. At our faculty he was once elected for the most excellent student in mathematics. He also received a Pro Scientia award that is given for the best work at a nationwide competition for university students. He was then admitted to the Computer Science PhD program where he was among the very few students who finished his thesis within the regular three years of the scholarship in 2001. He received the habilitation title in 2010. Before 2010 he was assistant at the department of computer algorithms and artificial intelligence, then in 2010 he became Professor and the Head of the department.

His research interests were very broad: he had results among others in online algorithms, in combinatorial optimization, in scheduling and in automata theory. He published 56 papers in total. He applied for the title "Doctor of Sciences" at the Hungarian Academy of Sciences in 2015, but this process could never be completed. Professor Imreh had wide international academic connections. He was a TEMPUS scholar in Utrecht, then he spent 6 months as a visiting scholar in Graz. In 2001-2002 he spent a year as a postdoc fellow at the Max Planck Institute in Saarbrücken. In 2007-2008, he was a visiting scholar at the University of Kyoto. In 2012 and 2015 he was a Humboldt fellow in Berlin. He participated in organizing international conferences and served as a referee for well-known journals.

He was an active participant in cooperation with Hungarian researchers and in different organizations. He received the Pro Scientia prize, the Kalmár László prize and the Farkas Gyula prize. He was also awarded a Békési György scholarship and a Bolyai János scholarship. He participated in different projects financed by OTKA, NKFP and TÁMOP. He was secretary of the Computer Science Doctoral School of our university, and member of the Informatics and Computer Science Committee of the Hungarian Academy of Sciences. He was also editor of Acta Cybernetica, an international journal published by the Institute of Computer Science at the University of Szeged. 
Professor Imreh was an outstanding, internationally acknowledged personality of our Institute. He was hard working and at the same time good-humored and even-handed. Without doubt, he had great potential and a great future ahead of him.

We miss you, Csanád.

Szeged, June 2018

\section{János Csirik}

Department of Computer Science

University of Szeged, Hungary 